\title{
The Effect of Service Quality and Facilities on Purchasing Decisions at UD. Bintang Petani Jaya in Pematangsiantar
}

\author{
Risma Munthe1, Adat Muli Peranginangin ${ }^{2}$ \\ ${ }^{1}$ Universitas Simalungun, Indonesia \\ ${ }^{2}$ STIE Surya Nusantara, Indonesia \\ rismamunthe66@gmail.com, adatperanginangin09@gmail.com
}

\begin{abstract}
This research is based on a casual relationship that is causal in nature, there are independent variables (variables that influence), dependent variables (variables that are affected) and mediating variables (variables that affect the relationship between the independent variable and the independent variable. Based on the results, it can be seen that the coefficient of determination (adjusted R2) is 0.403. This value means that the effect of the independent variable (service quality and facilities) on the dependent variable (purchase decision) is $40.3 \%$ while the remaining $59.7 \%$ is influenced by the other purchasing decision factors that are not examined. Based on the results of the F test, it is known that the significant level value obtained is 0,000 and it is smaller than the significant standard at the level of trust $5 \%$ or 0.05 and the comparison between $F$ count and $F$ table, where $F$ counts are 15,507 is greater than $F$ table which is 2,922, so it can be It is concluded that Ha is accepted or the quality of services and facilities has a significant effect on purchasing decisions.
\end{abstract}

Keywords

service quality; facilities; buying decision

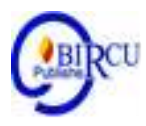

\section{Introduction}

The purpose of the quality of service and facilities in a company in offering products is to attract consumer sympathy to make purchases in order for the company to make a profit. The profits of a company can be obtained from customers or consumers. Today it is believed that the main key to winning the competition is providing satisfaction to consumers which has an impact on consumer purchasing decisions. Consumer purchasing decisions will be realized if they get what they want / need, one of the factors that influence purchasing decisions, namely in terms of the quality of service they get.

It is stated service quality is a dynamic resources covering the product of goods or services, human, process, and environment that meet user expectation (Sahfaq et.al in Sukesi, Yunus, 2018). According to (Davies in Arief, 2018: 117), quality is a dynamic condition related to products, services, people, processes, and the environment that meet or exceed expectations. According to (Kotler in Arief, 2018: 117), quality is the overall characteristics and characteristics of a product or service that affect its ability to satisfy stated or implied needs.

Service quality has an impact on consumer purchasing decisions. Because a good service quality will also have a good impact on purchasing decisions. According to (Sangadji and Sopiah in Putri, Wongkar, Michael, 2020), because services have a high quality of experience and trust, the buyers will have more risks. First, service consumers generally rely on word of mouth rather than advertising. Second, they are relying heavily on price, officers, and physical instructions to judge its quality. Third, they are very loyal to service providers who satisfy them. Service firms face three tasks, namely increasing 
competitive differentiation, quality and service, and productivity. According to (William in Alma, 2018: 245), service quality is something that can be identified as an intangible separately, offered to meet needs.

As has been explained above that "one of the factors to reach a purchasing decision that is by improving the quality of service". This statement can be interpreted that human resources play a very dominant role in the activities or activities of a company. The quality of internal service will encourage the realization of purchasing decisions and will grow a sense of desire to come back for a visit. The main objective in providing services is to achieve purchasing decisions which are marked by an increase in the number of sales of the product being offered. With the creation of these purchasing decisions, the company will gradually encourage consumers to establish good relationships with the possibility of repeated purchasing decisions for the same consumers.

UD. Bintang Petani Jaya is a trading business that is engaged in selling fertilizers, medicines for agriculture, and feed for fish. UD. Bintang Petani Jaya is located at Jln. Parapat No.100 Pematangsiantar. Currently there are quite a lot of businesses that resemble UD. Bintang Petani Jaya, so that UD. Bintang Petani Jaya must be able to maintain a good relationship between business owners and consumers so that UD business life can take place well. Bintang Petani Jaya in the future. Due to the increasing competition in the business of selling fertilizers and medicines for agriculture in Pematangsiantar, UD. Bintang Petani Jaya carries out various strategies to maintain the continuity of its business, especially by paying attention to existing facilities. Because the facility is also one of the things that should be considered by consumers who come to visit. Because the perceptions obtained from consumer interactions with facilities affect consumer interest in visiting and making purchase decisions. According to (Gronroos in Huriyati, 2019: 33), services are classified based on: types of services, professional services, other services, types of customers, individuals and organizations. According to (Manullang, 2012: 38), physical facilities are very influential on business activities, the effects are positive and some are negative. An environment that is positive is to provide conveniences in business activities, while a negative one is an obstacle in the implementation of business objectives

Based on the results of the recapitulation of the amount of income / income at UD. Bintang Petani Jaya is known that there has been an increase and decrease in income / income during the last three months related to complaints about the quality of services and facilities provided by UD. Bintang Petani Jaya in Pematangsiantar. The following will describe the complaints and problems that have decreased Bintang Petani Jaya's income / turnover, namely as follows: consumer complaints due to the lack of friendly services provided, as well as the parking facilities provided by UD. Bintang Petani Jaya.

The purpose of this research is to determine the extent of the influence of service quality on purchasing decisions and to determine the extent of the influence of facilities on purchasing decisions at UD. Bintang Petani Jaya in Pematangsiantar.

\section{Research Methods}

This research is based on a casual relationship that is causal in nature, so there are independent variables (variables that affect), dependent variables (variables that are influenced) and mediating variables (variables that affect the relationship between the independent variable and the independent variable. SPSS data processing 24. Primary data is data collected by the researcher where the data has never been previously collected, either in a certain way or over a certain period of time data obtained directly from respondents using a questionnaire. The questionnaire was distributed to consumers to be 
studied. Data includes: gender, age, and occupation. Secondary data is data collected by other people, not the researcher himself, namely in the form of data containing documentation, notes, writings that support the theory. Secondary data is in the form of a general description of the research object

The operational definition of a variable is an attribute or nature or value of an object or activity that has certain variations that are determined by the researcher to be studied and then draw conclusions. In this study, there are two independent variables and one dependent variable. Sample is part of the number and characteristics possessed by the population in (Sugiyono, 2017: 81). To determine the sample that will be used, the next step is to determine how to draw a sample from the existing population. Determining the sample taken using a non-probability sampling approach, where not all members of the population in the same position have the opportunity to be selected as a sample. The sampling method used in this research is accidental sampling, which is a technique used by chance. In this study, the sampling that is meant by chance is found by chance consumers who come and make purchases at UD. Bintang Petani Jaya in Pematangsiantar.

\section{Results and Discussion}

Respondent identity is a description of consumers who are respondents in the study, which can be seen from their gender, age and last education. Based on the processed data, the results of the distribution of respondents based on gender in this study can be seen in the table below:

Table 1. Respondents by Gender

\begin{tabular}{|c|c|c|}
\hline Gender & Amount & Percentage \\
\hline Male & 25 & $57 \%$ \\
\hline Female & 19 & $43 \%$ \\
\hline Amount & $\mathbf{4 4}$ & $\mathbf{1 0 0 \%}$ \\
\hline
\end{tabular}

Source: Primary data processed, 2020

Based on the table above, it can be concluded that the gender of the most dominant respondents is male with a total of 25 people with a percentage of $57 \%$. While the lowest was female as many as 19 people with a percentage of $43, \%$. According to the study of 44 respondents with a classification based on age can be shown in the following table:

Table 2. Respondents by Age

\begin{tabular}{|l|c|c|}
\hline Age & Amount & Persentage \\
\hline 21-30 years & 14 & $32 \%$ \\
\hline $31-40$ years & 21 & $48 \%$ \\
\hline 41-50 years & 9 & $20 \%$ \\
\hline Amount & 44 People & $\mathbf{1 0 0 \%}$ \\
\hline
\end{tabular}

Source: Primary data processed, 2020

From the table above, it can be concluded that the most dominant age of respondents is $31-40$ years old, amounting to 21 people with a percentage of $48 \%$, then those aged $\geq 50$ years are 44 people with a percentage of 32\%, respondents who have 21-30 years old are 6 people with a percentage of $20 \%$, the lowest respondents were at the age of 41-50 years of 9 people with a percentage of $20 \%$ and then there was no age $\leq 20$ years. 
The results of data analysis from the questionnaire attachment, a data analysis table can be made as follows:

Table 3. Distribution of Respondents' Answers to Variable (X1) Quality of Service

\begin{tabular}{|c|c|c|c|c|c|c|c|c|c|c|c|c|}
\hline \multirow[b]{2}{*}{ ITEM } & \multicolumn{2}{|c|}{93} & \multicolumn{2}{|c|}{8} & \multicolumn{2}{|c|}{$\mathrm{N}$} & \multicolumn{2}{|c|}{$\mathbb{T S}$} & \multicolumn{2}{|c|}{ 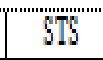 } & \multicolumn{2}{|c|}{ TOTAL } \\
\hline & $\mathrm{F}$ & 96 & I & $\%$ & $E$ & $\%$ & F & $\%$ & $E$ & $\bar{y}$ & $\bar{F}$ & 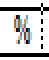 \\
\hline X1.1 & 9 & 20,5 & 26 & 59,1 & 9 & 20.5 & $\overline{0}$ & 0 & 0 & 0 & 44 & 100: \\
\hline X1.2 & 8 & 18,2 & 26 & 56,8 & 11 & 25 & 0 & 0 & 0 & 0 & 44 & $100:$ \\
\hline$X 1.3$ & 3 & 6,8 & 32 & $\overline{27}$, & 9 & 20,5 & 0 & 0 & 0 & 0 & 44 & $\overline{100}$ \\
\hline X1.4 & 5 & 11,4 & 37 & 84,1 & 2 & 4,5 & 0 & 0 & 0 & 0 & 44 & $100:$ \\
\hline$\overline{\mathrm{X} 1.5}$ & 8 & 18,2 & 28 & 63.6 & 8 & 182 & $\pi$ & 0 & 0 & 0 & 44 & $\overline{100}$ \\
\hline
\end{tabular}

Source: Primary data processed by SPSS V 22, 2020

In item 1, 9 respondents stated strongly agreed (20.5\%), 26 people agreed $(59.1 \%)$, and 9 people stated that they were neutral $(20.5 \%)$. Item 2 of respondents who strongly agree with 8 people $(18.2 \%)$, who agree with 25 people $(56.8 \%)$, Item 3 of respondents who strongly agree 3 people $(6.8 \%)$, who agree 32 people $(72.7 \%)$, and those who stated that they were neutral were 9 people $(20.5 \%)$. Item 4 of respondents who stated strongly agree with 5 people (11.4\%), 37 people who agreed (84.1\%), and 2 people who stated that they were neutral $(4.5 \%)$. Item 5 of respondents who stated strongly agree with 8 people (18.2\%), 28 people $(63.6 \%)$ who stated that they agreed, and 8 people who stated that they were neutral $(18.2 \%)$ and 11 people who stated that they were neutral $(25 \%)$.

Table 4. Distribution of Variable Respondents' Answers (X2) Facilities

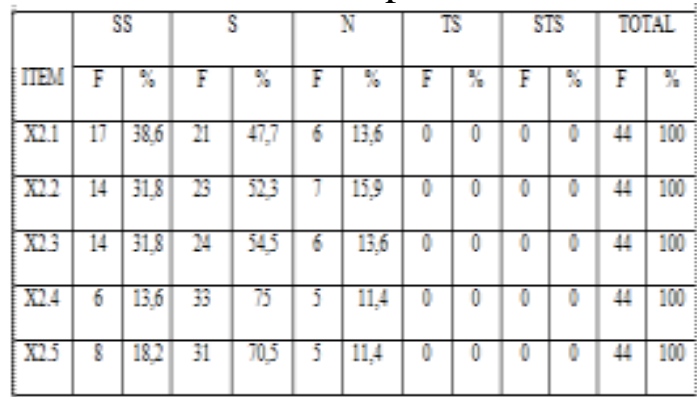

Source: Primary data processed by SPSS V 22, 2020

In item 1, respondents who strongly agreed with 17 people $(38.6 \%), 21$ people $(47.7 \%)$ agreed to agree, and 6 people who stated that they were neutral (13.6\%). Item 2 of respondents who stated strongly agree with 14 people (31.8\%), 23 people $(52.3 \%)$ who stated that they agreed, and 7 people who stated that they were neutral (15\%). Item 3 of respondents who stated strongly agree with 14 people $(31.8 \%), 24$ people who agreed $(54.5 \%)$, and 6 people who stated that they were neutral (13.6\%). Item 4 of the respondents who stated strongly agree with 6 people $(13.6 \%), 33$ people $(75 \%)$ who stated that they agreed, and 5 people who stated that they were neutral $(11.4 \%)$. Item 5 respondents who strongly agreed with 8 people $(18.2 \%)$, who agreed to 31 people $(70.5 \%)$, and those who stated that they were neutral 5 people $(11.4 \%)$ 
Table 5. Distribution of Respondents' Answers to Variable (Y) Purchase Decisions

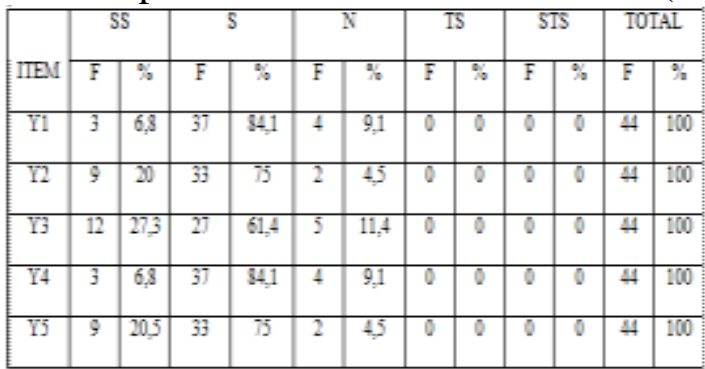

Source: Primary data processed by SPSS V 22, 2020

In item 1 , respondents stated that 3 people strongly agreed $(6.8 \%), 37$ people $(84.1 \%)$ stated that they agreed, and 4 people stated that they were neutral $(9.1 \%)$. Item 2 of the respondents who stated strongly agree with 9 people (20\%), 33 people $(75 \%)$ who stated that they agreed, and 2 people who stated that they were neutral $(4.5 \%)$. Item 3 of respondents who stated strongly agree with 12 people $(27.3 \%), 27$ people $(61.4 \%)$ who stated that they agreed, and 5 people who stated that they were neutral (11.4\%). Item 4 of respondents who stated that 3 people strongly agreed $(6.8 \%)$, who stated that 37 people $(84.1 \%)$ agreed, and 4 people who stated that they were neutral $(9.1 \%)$. Item 5 of the respondents who stated strongly agree with 9 people $(20.5 \%), 33$ people $(75 \%)$ who stated that they agreed, and 2 people who stated that they were neutral $(4.5 \%)$.

\subsection{Data Testing Results}

a. Validity Test

The validity test is used to measure whether a questionnaire is valid or not. A questionnaire is said to be valid if the questions on the questionnaire are able to reveal something that will be measured by the questionnaire. In testing the validity, a measuring instrument in the form of a computer program is used, namely SPSS For Windows 22, and if a measuring instrument has a significant correlation between the item score and the total score, it is said that the score tool is valid.

Table 6. Validity Test Results

\begin{tabular}{|c|c|c|c|c|}
\hline No & Pertanyaan & $\begin{array}{c}\mathrm{R} \\
\text { hitung }\end{array}$ & R tabel & Keterangan \\
\hline \multirow[t]{6}{*}{1} & $\begin{array}{c}\text { Kualitas pelaxanan } \\
\left(\mathbf{x}_{1}\right)\end{array}$ & & & \\
\hline & Pertanyaan 1 & 0,689 & 0,297 & Valid \\
\hline & Pertanyaan 2 & 0,769 & 0,297 & Valid \\
\hline & Pertanyaan 3 & 0,791 & 0,297 & Valid \\
\hline & Pertanyaan 4 & 0,628 & 0,297 & Valid \\
\hline & Pertanyaan 5 & 0,786 & 0,297 & Valid \\
\hline \multirow[t]{6}{*}{2} & Fasilitas $\left(\mathbf{X}_{2}\right)$ & & & \\
\hline & Pertanyaan 1 & 0,681 & 0,297 & Valid \\
\hline & Pertanyaan 2 & 0,874 & 0,297 & Valid \\
\hline & Pertanyaan 3 & 0,867 & 0,297 & Valid \\
\hline & Pertanyaan 4 & 0,867 & 0,297 & Valid \\
\hline & Pertanyaan 5 & 0,814 & 0,297 & Valid \\
\hline \multirow[t]{6}{*}{3} & $\begin{array}{c}\text { Keputusan Pembelian } \\
\text { (Y) }\end{array}$ & & & \\
\hline & Pertanyaan 1 & 0,708 & 0,297 & Valid \\
\hline & Pertanyaan 2 & 0,888 & 0,297 & Valid \\
\hline & Pertanyaan 3 & 0,801 & 0,297 & Valid \\
\hline & Pertanyaan 4 & 0,708 & 0,297 & Valid \\
\hline & Pertanyaan 5 & 0,888 & 0,297 & Valid \\
\hline
\end{tabular}

Source: Primary data processed, 2020 
The validity test will test each variable used in this study, where all research variables contain 18 questions that must be answered by the respondent. The criteria used in determining whether the questions used in this study are valid or not are as follows: confidence level $=95 \%(\alpha=5 \%)$, degrees of freedom $(\mathrm{df})=\mathrm{n}-2=44-2=42$, obtained $\mathrm{r}$ table $=0.297$. If $r$ count (for each item can be seen in the Corrected Item - Total Correlation column) is greater than $r$ table and the value of $r$ is positive, then the statement item is said to be valid. Based on the analysis that has been done, the results of the validity test can be shown in table 4.6 as follows:

Table 6 shows that all indicators used to measure the variables used in this study have a correlation coefficient that is greater than $r$ table $=0.297(r$ table value for $n=34)$, so all indicators are valid.

\section{b. Reliability Test}

The reliability test is intended to measure a questionnaire which is an indicator test of the variable. Reliability was measured by Cronbach's Alpa statistical test. A variable is said to be reliable if it gives a Cronbach's Alpa value> 0.60 .

Table 7. Reliability Test

\begin{tabular}{|l|c|c|c|}
\hline \multicolumn{1}{|c|}{ Variabel } & $\begin{array}{c}\text { Cronbach's } \\
\text { Alpha }\end{array}$ & N of Items & Status \\
\hline Kualitas Pelayanan (X1) & 0,777 & 5 & Reliabel \\
\hline Fasilitas (X2) & 0,870 & 5 & Reliabel \\
\hline KeputusanPembelian(Y) & 0,854 & 5 & Reliabel \\
\hline
\end{tabular}

Source: Primary data processed, 2020

From these results it can be said that each construct is reliable because it is greater than 0.6, then the items in each of these variable concepts are suitable for use as a measuring tool.

\section{c. Classic Assumption Test}

\section{Normality Test}

The normality test aims to test whether the regression model, the dependent variable, the independent variable or both of them has a normal distribution or not. A good regression model is to have normal data or the distribution of statistical data on the diagonal axis of the normal distribution graph. 


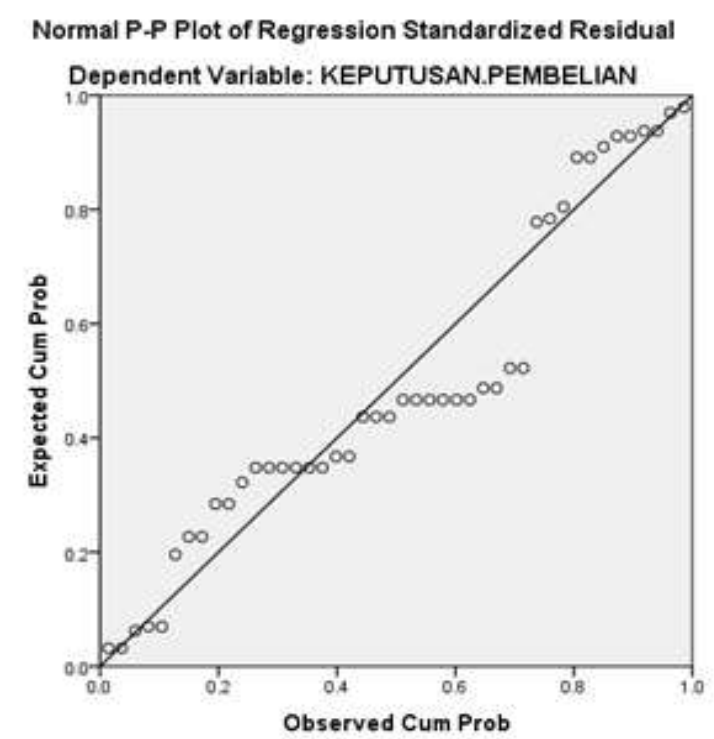

Figure 1. Scatter Plot Graph Normality Test

Source: primary data processed, 2020

In the SPSS output above, seen from the Normal P-P Plot diagram, the plots follow a straight line, so the diagram meets the assumption of normality.

\section{Multicollinearity Test}

Multicollinearity is a condition where there is a linear relationship or high correlation between each independent variable in the regression model. Multicollinearity usually occurs when most of the variables used are interrelated in a regression model. Therefore multicollinearity problem does not occur in simple linear regression which only involves one independent variable.

In this study, the technique for detecting the presence or absence of multicollinearity in regression is looking at the Variance Inflection Factor (VIF) value, and the Tolerance value is close to 1 , and the VIF value is around 1 and not more than 10 , it can be concluded that there is no Multicollinearity between the independent variables. in the regression model.

Table 8. Multicollinearity Test

\begin{tabular}{|c|c|c|c|c|c|c|c|c|}
\hline \multicolumn{9}{|c|}{ Coefficients: } \\
\hline \multirow{2}{*}{\multicolumn{2}{|c|}{ Model }} & \multicolumn{2}{|c|}{$\begin{array}{l}\text { Unstandardized } \\
\text { Coefficients }\end{array}$} & \multirow{2}{*}{\begin{tabular}{|c}
$\begin{array}{c}\text { Standardiz } \\
\text { ed } \\
\text { Coefficient } \\
\mathbf{s}\end{array}$ \\
Beta
\end{tabular}} & \multirow[t]{2}{*}{$\mathrm{t}$} & \multirow[t]{2}{*}{ Sig. } & \multicolumn{2}{|c|}{$\begin{array}{l}\text { Collinearity } \\
\text { Statistics }\end{array}$} \\
\hline & & B & Std. Error & & & & $\begin{array}{c}\text { Toleran } \\
\text { ce }\end{array}$ & VIF \\
\hline \multirow{3}{*}{1} & (Constant) & 8.115 & 2.294 & & 3.538 & .001 & & \\
\hline & $\begin{array}{l}\text { KUALITAS.PELA } \\
\text { YANAN }\end{array}$ & .265 & .130 & .289 & 2.035 & .048 & .687 & 1.455 \\
\hline & FASILITAS & .341 & .108 & .449 & 3.159 & .003 & .687 & 1.455 \\
\hline
\end{tabular}

Source: Primary data processed, 2020

Based on the output of the use of the SPSS application above, it is known that: the tolerance value for service quality and facilities $(\mathrm{X} 1, \mathrm{X} 2)$ is 1.455 , greater than 0.10 . Meanwhile, the VIF value of service quality and facilities (X1) is $1.455<10.00$. So it can be concluded that there is no multicollinearity. 


\section{Heteroscedasticity Test}

The heteroscedasticity test aims to test whether the regression model has an inequality of variants from one observation to another.

Scatterplot

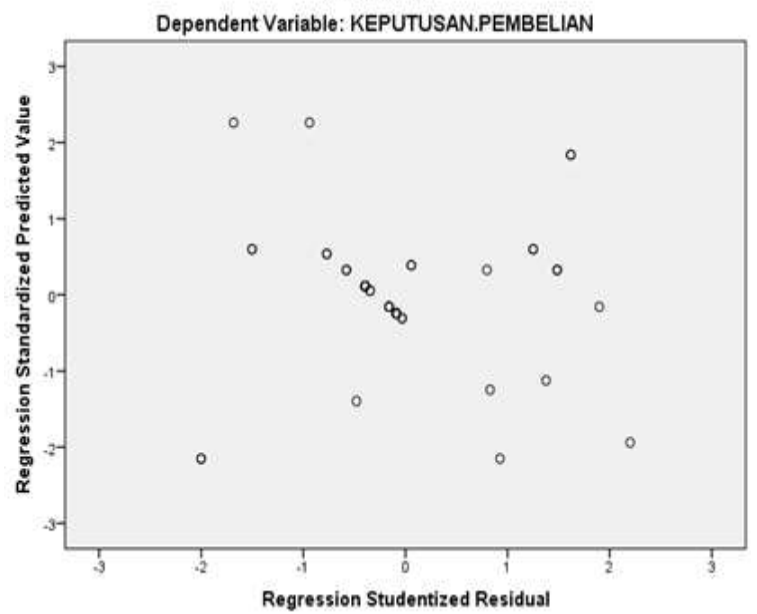

Figure 2. Heteroscedasticity Test

Source: Processed data, 2020

From the Scatterplots graph, it can be seen that the dots spread randomly and are spread both above and below the number 0 on the $\mathrm{Y}$ axis. This can be concluded that there is no heteroscedaticity in the regression model so that the regression model is suitable to be used to predict the dependent variable of buyer decisions based on the input of the independent variable quality services and facilities at UD. Bintang Petani Jaya in Pematangsiantar.

\section{Autocorrelation Test}

The autorrelation test aims to determine whether there is a correlation between members or observation data that is located in a row. To detect the presence of autorrelation, it is carried out with the following conditions: If the DW number is below -2 it means that there is positive autorrelation, If the DW number is between -2 to +2 , it means that there is no autocorrelation and if DW is above +2 it means that there is positive autorrelation. The Durbin Watson value on the model summary is 1.647 , so because 1.647 means between -2 means that there is no autocorrelation.

Table 9. Autocorrelation Results

\begin{tabular}{|c|c|c|c|c|c|c|c|c|c|c|}
\hline \multicolumn{11}{|c|}{ Model Summarx." } \\
\hline & \multirow[t]{2}{*}{$\mathrm{R}$} & \multirow{2}{*}{\begin{tabular}{|c|}
$R$ \\
Squar \\
e
\end{tabular}} & \multirow{2}{*}{$\begin{array}{c}\text { Adjusted } \\
\text { R } \\
\text { Square }\end{array}$} & \multirow{2}{*}{$\begin{array}{c}\text { Std. } \\
\text { Error of } \\
\text { the } \\
\text { Estimate }\end{array}$} & \multicolumn{5}{|c|}{ Change Statistics } & \multirow{2}{*}{\begin{tabular}{|l} 
Durbin- \\
Watson
\end{tabular}} \\
\hline & & & & & $\begin{array}{c}\mathrm{R} \\
\text { Square } \\
\text { Change }\end{array}$ & $\begin{array}{c}F \\
\text { Chan } \\
\text { ge }\end{array}$ & df1 & $d+2$ & $\begin{array}{l}\text { Sig. F } \\
\text { Change }\end{array}$ & \\
\hline 1 & $.656^{\mathrm{N}}$ & .431 & .403 & 1.47556 & .431 & $\begin{array}{r}15.50 \\
7\end{array}$ & 2 & 41 & .000 & 1.647 \\
\hline \multicolumn{11}{|c|}{ 9. Predictors: (Constant), FASILITAS, KUALITAS.PELAYANAN } \\
\hline & & & KEPPUT & TUSAN PEI & MBELLIAN & & & & & \\
\hline
\end{tabular}

Source: Primary data processed, 2020 


\section{d. Results of Data Analysis}

\section{Multiple Linear Regression Analysis}

In an effort to answer the problems in this study, multiple regression analysis is used. The program to analyze this regression uses SPSS 22 For Windows software, to analyze the effect of the independent variables, namely service quality and facilities, on the dependent variable, namely the purchase decision. The results of data processing using the SPSS program are as follows:

Table 10. Regression Measurement Results

\begin{tabular}{|c|c|c|c|c|c|c|c|c|}
\hline \multicolumn{9}{|c|}{ Coenfficients: } \\
\hline \multirow{2}{*}{\multicolumn{2}{|c|}{ Model }} & \multicolumn{2}{|c|}{$\begin{array}{l}\text { Ynstanderdized } \\
\text { Coefficients }\end{array}$} & \multirow{2}{*}{\begin{tabular}{|c|}
$\begin{array}{c}\text { Standardiz } \\
\text { ed } \\
\text { Coefficient } \\
5\end{array}$ \\
Beta \\
\end{tabular}} & \multirow[t]{2}{*}{$t$} & \multirow[t]{2}{*}{ Sig. } & \multicolumn{2}{|c|}{$\begin{array}{l}\text { Collinearity } \\
\text { Statistics }\end{array}$} \\
\hline & & B & Std. Error & & & & $\begin{array}{c}\text { Toleran } \\
\mathrm{ce}\end{array}$ & VIF \\
\hline \multirow{3}{*}{1} & (Constant) & 8.115 & 2.294 & & 3.538 & .001 & & \\
\hline & $\begin{array}{l}\text { KUALITAS.PELA } \\
\text { YANAN }\end{array}$ & .265 & .130 & .289 & 2.035 & .048 & .687 & 1.455 \\
\hline & FASILITAS & 341 & .108 & .449 & 3.159 & .003 & .687 & 1.455 \\
\hline
\end{tabular}

Source: Primary data processed, 2020

Based on the results of regression measurements shown in Table 4.10. then the regression equation that is formed is:

\section{$\mathrm{Y}=\mathbf{8 . 1 1 5}+\mathbf{0 . 2 6 5} \mathrm{X} 1+0.341 \mathrm{X} 2$}

The regression equation above can be concluded as follows:

a. The constant value of the multiple linear regression equation is 8.115 , meaning that if the service quality variable $(\mathrm{X} 1)=0$ and the facility variable $(\mathrm{X} 2)=0$, then the value of the purchasing decision variable $(\mathrm{Y})=8.115$

b. The regression coefficient of the service quality variable (X1) is $26.5 \%$, meaning that the service quality (X1) has a positive effect on purchasing decisions (Y) will increase.

c. The facility variable regression coefficient (X2) is $34.1 \%$, meaning that the facility has increased by $1 \%$, so the purchase decision (Y) will increase by $46.1 \%$.

The results of the multiple regression above indicate that the independent variable, namely the quality of service and facilities, has a positive effect on the dependent variable, namely the purchase decision. It's just that for (X1) service decisions are only $26.5 \%$, this means X1 service decisions are only $26.5 \%$, for X2 the facilities are $34.1 \%$, this means that the facilities provided by the company are still not optimal so that the service decisions on facilities only $34.1 \%$. Where any increase that occurs in the independent variable will also be followed by an increase in the dependent variable.

\section{The $t$ test}

The $t$ test is intended to determine how far the influence of one independent variable (service quality and facilities) individually in explaining the dependent variable (purchase decision). The results of the $t$ test in this study can be seen in table 4:11 below: 
Table 11. Result of t test analysis

\begin{tabular}{|c|c|c|c|c|c|c|}
\hline \multicolumn{7}{|c|}{ Coefficients. } \\
\hline \multirow{2}{*}{\multicolumn{2}{|c|}{ Model }} & \multicolumn{2}{|c|}{$\begin{array}{l}\text { Yostandardized } \\
\text { Coefficients }\end{array}$} & \multirow{2}{*}{\begin{tabular}{|c|}
$\begin{array}{c}\text { Standardized } \\
\text { Coefficients }\end{array}$ \\
Beta \\
\end{tabular}} & \multirow[t]{2}{*}{ T } & \multirow[t]{2}{*}{ Sig. } \\
\hline & & B & Std. Error & & & \\
\hline \multirow{3}{*}{1} & (Constant) & 7.090 & 2.294 & & 3.538 & .001 \\
\hline & KUALITAS.PELAYANAN & .238 & .130 & .289 & 2.035 & .048 \\
\hline & FASILITAS & .461 & 108 & .449 & 3.159 & .003 \\
\hline
\end{tabular}

Source: Primary data processed, 2020

1. Variable X1 (Quality of Service)

The steps for carrying out the $\mathrm{t}$ test are as follows:

$\mathrm{HO}=0$ : Service quality variables do not have a positive and significant effect on decisions at UD. UD. Bintang Petani Jaya in Pematangsiantar.

$\mathrm{Ha} \neq 0$ : Service quality variables have a positive and significant effect on service quality on purchasing decisions at UD. Bintang Petani Jaya in Pematangsiantar.

The level of significance used was $(0.05 \alpha=5 \%)$. Based on table 4.11 , the significant service quality variable is 0.048 and greater than $0.05(0.048 \leq 0.05)$, so it can be concluded that the service quality variable has a positive and significant effect on purchasing decisions. Based on table 4.11, the t count for the service quality variable is 2.035 .

The $t$ distribution table is sought at $\alpha=5 \%(0.05)$ with degrees of freedom (Df) $=n$ $\mathrm{k}$ or $44-3=41$, using the Microsoft Excel formula by typing in an empty cell $=$ Tinv (0.05.41) then press enter. The result is 2.01954097 (2.019). Comparison of $t$ count and $t$ table we can see that the value of $t$ count $>$ from the value of $t$ table, namely 2.035>2.019. So based on the comparison of the value of $t$ and $t$ table it can be concluded that the variable service quality has a significant effect on purchasing decisions.

Based on the level of significance, if the level of significance is below or less than $5 \%$. From the research results obtained a significance level of $0.048<0.05$. So it can be concluded that service quality has a significant effect on the dependent variable (purchase decision). From all the explanations and statistical results from the research, it can be concluded that the hypothesis Ha1 is accepted, meaning that the X1 variable has a positive and significant effect on purchasing decisions at UD. Bintang Petani Jaya in Pematangsiantar.

\section{Variable X2 (Facilities)}

The steps for performing the $t$ test are as follows:

$\mathrm{HO}=0$ : The facility variable does not have a positive and significant effect on purchasing decisions at UD. Bintang Petani Jaya in Pematangsiantar.

$\mathrm{Ha} \neq 0$ : Facility variables have a positive and significant effect on purchasing decisions at UD. Bintang Petani Jaya in Pematangsiantar.

The level of significance used was $(0.05 \alpha=5 \%)$. Based on table 4.11 , the significant facility variable is 0.003 which is smaller $0.05(0.003 \leq 0.05)$ so it can be concluded that the facility variable has a positive and significant effect on purchasing decisions.

Based on table 11 , the $t$ count for the facility variable is 3.155 . The $t$ distribution table is sought at $\alpha=5 \%(0.05)$ with degrees of freedom (df) $=\mathrm{n}-\mathrm{k}$ or $44-3=41$, using the Microsoft Excel formula by typing in an empty cell $=$ Tinv $(\mathbf{0 . 0 5 . 4 1})$ then press enter. The result is 2.01954097 (2.019). 
Comparison of $t$ count and t table we can see that the value of $t$ count $>$ from the value of t table, namely 3.155> 2.019 so based on the comparison of the value of $t$ count and $\mathrm{t}$ table it can be concluded that the facility variable has a significant effect on purchasing decisions. Based on the level of significance, if the level of significance is below or less than 5\%, the variable affects the dependent variable (purchase decision) and vice versa. From the research results obtained a significance level of 0.003 . So it can be said that the significant level of the facility variable is below the standard, meaning that this variable has an influence on the dependent variable (purchase decision).

According to all of the explanations and statistical results from the study, it can be concluded that the hypothesis $\mathrm{Ha} 2$ is accepted, meaning that the facility variable has a positive and significant effect on purchasing decisions at UD. Bintang Petani Jaya in Pematangsiantar.

According to the results of multiple linear regression and t test in table 4.11 shows that the two regression coefficients are positive and significant. From the regression model, it can be further explained as follows:

a. The service quality variable (X1) has a positive and significant effect on purchasing decisions $(Y)$ with a regression value of $26.5 \%$ and a $t$ value. count $=2.035$ with a significance level of 0.048 .

b. The facility variable (X2) has a positive and significant effect on purchasing decisions (Y) with a regression value of $34.1 \%$ and the $t$ value $=3.155$ with a significant level of 0.003 .

\section{The F Test}

The $\mathrm{F}$ test is intended to determine how far the influence of independent variable (service quality and facilities) simultanneously in explaining the dependent variable (purchase decision). The results of the f test in this study can be seen in table 4:12 below:

Table 12. Regression Analysis Results Simultaneously (F Test)

\begin{tabular}{|c|c|c|c|c|c|c|}
\hline \multicolumn{7}{|c|}{ ANQVA: } \\
\hline Mod & & Sum of Squares & $\mathrm{Df}$ & Mean Square & $\mathrm{F}$ & Sig. \\
\hline \multirow{3}{*}{1} & Regression & 67.527 & 2 & 33.764 & 15.507 & $.000^{\circ}$ \\
\hline & Residual & 89.268 & 41 & 2.177 & & \\
\hline & Total & 156.795 & 43 & & & \\
\hline
\end{tabular}

Source: Primary data processed, 2020

The $\mathrm{F}$ test is used to test the effect of the independent variables on the dependent variable simultaneously. In connection with the proposed hypothesis, the steps for carrying out the $\mathrm{F}$ test are as follows:

Ho $=0$ : there is no significant effect on each of the independent variables (quality of service and facilities) on the dependent variable (Purchase Decision).

$\mathrm{Ha} \neq 0$ : there is a significant effect on each of the independent variables (quality of service and facilities) on the dependent variable (Purchase Decision).

The significant level that used is 0.000 or $0 \%$, which means that the independent variable (quality of service and facilities) has a significant effect on the dependent variable (purchasing decisions) with a significance level of $0 \%$. equation:

By using the $0 \%$ confidence level, $\alpha=0 \%$, df 1 can be determined by the following 
$\mathrm{df}=1$ number of variables; means df $1=3$ while df $2=\mathrm{n}-\mathrm{k}-1$; means df $2=40 ;$ (44 3 - 1) so, you can search for it in the Microsoft Excel program by typing in a blank cell = FINV $(0.05,40,30)$ and then pressing enter. The result is $1.79179119(1,791)$.

Ho is accepted if $F$ count $\leq F$ table

Ho is rejected if $\mathrm{F}$ count $\geq \mathrm{F}$ table

Comparing F count with F table Value F count > F table $(15,507>1,791)$

Based on statistical testing with the $\mathrm{F}$ test method, where the significant level obtained is smaller, namely 0,000 from the significant standard, namely $5 \%$ or 0.05 and the comparison between $\mathrm{F}$ count and $\mathrm{F}$ table, where $\mathrm{F}$ counts are 15,507 is greater than $\mathrm{F}$ table which is 1,791 , then It can be concluded that $\mathrm{Ha}$ is accepted or the quality of service and facilities has a significant effect on purchasing decisions.

\section{Determination Test (R2)}

The coefficient of determination (R2) basically measures how far the model's ability to explain the variation of the dependent variable. The coefficient of determination is between zero ( 0 ) and one (1). The coefficient of determination can be seen in table 4:13 below:

Table 13. Coefficient of Determination (R2)

\begin{tabular}{|c|c|c|c|c|c|c|c|c|c|c|}
\hline \multicolumn{11}{|c|}{ Model Summary } \\
\hline \multirow{2}{*}{ Mo } & \multirow[t]{2}{*}{$\mathrm{R}$} & \multirow{2}{*}{\begin{tabular}{|c|}
$R$ \\
Squar \\
$e$
\end{tabular}} & \multirow{2}{*}{$\mid \begin{array}{c}\text { Adjusted } \\
R \\
\text { Square }\end{array}$} & \multirow{2}{*}{$\begin{array}{c}\text { Std. } \\
\text { Error of } \\
\text { the } \\
\text { Estimate }\end{array}$} & \multicolumn{5}{|c|}{ Change Statistics } & \multirow{2}{*}{$\begin{array}{l}\text { Durbin- } \\
\text { Watson }\end{array}$} \\
\hline & & & & & $\begin{array}{c}\mathrm{R} \\
\text { Square } \\
\text { Change } \\
\end{array}$ & \begin{tabular}{|c|}
$\mathrm{F}$ \\
Chan \\
$\mathrm{ge}$
\end{tabular} & df1 & $d f 2$ & $\begin{array}{c}\text { Sig. F } \\
\text { Change }\end{array}$ & \\
\hline 1 & $.656^{\circ}$ & .431 & .403 & 1.47556 & .431 & $\begin{array}{r}15.50 \\
7 \\
\end{array}$ & 2 & 41 & .000 & 1.647 \\
\hline
\end{tabular}

Source: Primary data processed, 2020

Multiple correlation analysis (R2) is used to determine the relationship between two or more independent variables (X1, X2) and the dependent variable (Y) simultaneously. The value of $\mathrm{R}$ ranges from 0 to 1 , the value getting closer to 1 means that the relationship is getting stronger, on the other hand the value is getting closer to 0 , the weaker the relationship is. The results of calculations using the SPSS version 20 program show that the coefficient of determination (adjusted R2) is 0.403 . This value means that the effect of the independent variable (service quality and facilities) on the dependent variable (purchase decision) is $40.3 \%$, while the remaining $59.7 \%$ is influenced by other purchasing decision factors that are not examined.

\subsection{Discussion}

a. The effect of service quality on purchasing decisions at UD. Bintang Petani Jaya in Pematangsiantar

The validity test shows that the calculated $r$ value of each indicator of the service quality variable is greater than the $\mathrm{r}$ table of 0.297 so that the indicator of the service quality is valid. The reliability test of the service quality variable with a Cronbach alpha value of 0.777 is greater than 0.6 , which means that the service quality variable is reliable. Independent variables tested individually in influencing UD purchasing decisions. Bintang Petani Jaya in Pematangsiantar is the quality of service (with a coefficient of 0.265 ) but not dominant in influencing purchasing decisions. 
Based on the significance level of the research results that the service quality obtained a significance level of $0.048<0.05$. So it can be concluded that service quality has a significant effect on purchasing decisions.

\section{b. Effect of Facilities on Purchasing Decisions of UD. Bintang Petani Jaya in Pematangsiantar}

The validity test shows that the calculated $r$ value of each facility variable indicator is greater than the $r$ table of 0.297 so that the indicator of the facility is valid. The reliability test of the facility variable with a Cronbach alpha value of 0.870 is greater than 0.6 , which means that the facility variable is reliable or reliable. The independent variable tested individually is dominant in influencing the purchasing decision of UD. Bintang Petani Jaya in Pematangsiantar is a facility (with a coefficient of 0.341 ).

Based on the level of significance of the research results that the facility obtained a significance level of $0.003<0.05$. So it can be concluded that consumer perceptions have a significant effect on purchasing decisions. It means that this variable is the most important in determining UD purchasing decisions. Bintang Petani Jaya in Pematangsiantar

\section{c. The Effect of Service Quality and Facilities on UD Purchasing Decisions. Bintang Petani Jaya in Pematangsiantar}

The validity test shows that the calculated $r$ value of each variable indicator of service quality and facilities is greater than $r$ table of 0.297 so that the indicator of the purchase decision is valid. The reliability test of the variable quality of services and facilities with a Cronbach alpha value of 0.854 is greater than 0.6 , which means that the variable quality of service and facilities is reliable or reliable.

The results of the F test show that the simultaneous influence of the two independent variables (service quality and facilities) on the dependent variable (purchasing decisions) on purchases at UD. Bintang Petani Jaya in Pematangsiantar with significant results. This is indicated by the magnitude of the $\mathrm{F}$ value of 15,507 with a significant level of 0.000 (less than 0.005). Meanwhile, from the calculation of the coefficient of determination (R2), it can be seen or concluded that the independent variables in this study are able to explain $40.3 \%$ of the dependent variable (service quality and facilities) at UD. Bintang Petani Jaya in Pematangsiantar. While the remaining $59.7 \%$ is influenced or explained by other variables not included in this research model.

\section{Conclusion}

Based on the results, it can be seen that the coefficient of determination (adjusted R2) is 0.403 . This value means that the effect of the independent variable (service quality and facilities) on the dependent variable (purchase decision) is $40.3 \%$, while the remaining $59.7 \%$ is influenced by other purchasing decision factors that are not examined.

Based on the results of the $\mathrm{F}$ test, it is known that the significant level value obtained is smaller, namely 0.000 from the significant standard, namely $5 \%$ or 0.05 and the comparison between $\mathrm{F}$ count and F table, where $\mathrm{F}$ counts are 15,507 is greater than F table which is 2,922, so it can be It is concluded that Ha is accepted or the quality of services and facilities has a significant effect on purchasing decisions. 


\section{References}

Alma. (2018). Manajemen Pemasaran \& Pemasaran Jasa. Edisi Revisi. CV. Alfabeta : Bandung

Arief. (2018). Pemasaran Jasa \& Kualitas Pelayanan. Bayumedia : Malang

Danang. Sunyoto. 2014. Praktik Riset Perilaku Konsumen. caps : Yogyakarta.

Eva. (2016). Pengaruh Kualitas Pelayanan dan Fasilitas dan Harga terhadap Keputusan Pelanggan Untuk Menggunakan Jasa Hotel Oval Surabaya. Sekolah Tinggi Ilmu Ekonomi Urip Sumoharjo : Surabaya

Hurriyati. (2019). Bauran Pemasaran. Loyalitas Konsumen. Alfabeta : Bandung

Manullang. (2012). Pengantar Bisnis. Indomedia Pustaka : Medan

Mardiyani. (2013). Analisis Pengaruh Kualitas Pelayanan dan Fasilitas Terhadap Kepuasan Pelanggan (Studi Pada SPBU 44.549 10 Ds.Wedelan Kec Bangsri, Jepara). Universitas Diponegoro : Semarang

Putri, A, P., Wongkar, A., Michael. Balliansa, M, R,. (2020). The Influence of Product Quality, Price, and Service Quality in Customer Loyalty at PT. Cybernetic Makmur Lestari. Budapest International Research and Critics Institute-Journal (BIRCIJournal). 3(4). P. 2864-2879. doi.org/10.33258/birci.v3i4.1306

Sukesi. Yunus, Eddy. (2018). Service Quality in Public Transport Services of the Provicial Intercity Transportation (AKDP) in East Java Indonesia. Budapest International Research and Critics Institute-Journal (BIRCI-Journal). 1 (4). P. 161-169

Sugiyono. 2017. Metode Penelitian Kuantitaif dan Kualitatif. Bandung : C.V Alfabeta

Sudaryano. (2016). Manajemen Pemasaran. Teori \& Implementasi. CV. ANDI OFFSET : Yogyakarta

Thamrin. (2012). Manajemen Pemasaran. Raja Grafindo Persada : Depok

Tjiptono. (2018). Pemasaran Jasa. CV. ANDI OFFSET : Yogyakarta 